\title{
PENDEKATAN TAM SEBAGAI ANALISIS PENGGUNAAN E-LEARNING PENDUKUNG SISTEM PEMBELAJARAN DIKLAT TEKNIS BALAI PELATIHAN PERTANIAN (BPP) LAMPUNG
}

\author{
Alhibarsyah, S.T., M.Kom \\ Dosen Sistem Informasi, STMIK Tunas Bangsa \\ Alhibarsyah.aal@gmail.com
}

\begin{abstract}
The development of technology, especially information technology, in the last decade shows rapid progress, both hardware, software, or other infrastructure that can support the creation of a reliable information system.

This study aims to evaluate the revenue model of e-learning as one of the supporting software technologies in the learning activities, with the approach Technology Acceptance Model (TAM). For statistical testing will be done with Structural Equation Modeling (SEM) in AMOS 20.0 software.

Based on the analysis and interpretation, the author sum up that flexibility, ease of e-learning to use, learn and understand the effectiveness and influence on training participants completion of the job training can even improve their performance, the effectiveness of high impact use of e-learning in Pusdiklat Teknis BPP Lampung, compliance use of e-learning by training influential training participants to frequency use of e-learning in Pusdiklat Teknis BPP Lampung, ease of use of $e$ learning also affect the willingness to use e-learning.
\end{abstract}

Keywords : e-learning, Diklat Teknis, BPP Lampung, TAM

\section{ABSTARK}

Perkembangan teknologi, khususnya teknologi informasi, dalam dekade terakhir menunjukkan kemajuan pesat, baik hardware, software, atau infrastruktur lain yang dapat mendukung terciptanya sistem informasi yang handal.

Penelitian ini bertujuan untuk mengevaluasi model pendapatan dari e-learning sebagai salah satu teknologi software pendukung dalam kegiatan belajar, dengan pendekatan Technology Acceptance Model (TAM). Untuk pengujian statistik akan dilakukan dengan Structural Equation Modeling (SEM) di software AMOS 20.0.

Berdasarkan analisis dan interpretasi, penulis meringkas bahwa fleksibilitas, kemudahan elearning untuk menggunakan, mempelajari dan memahami efektivitas dan pengaruh pada peserta diklat penyelesaian pelatihan kerja bahkan dapat meningkatkan kinerja mereka, efektivitas penggunaan dampak tinggi dari e-learning di Pusdiklat Teknis BPP Lampung, penggunaan kepatuhan e-learning dengan melatih peserta diklat berpengaruh terhadap frekuensi penggunaan elearning di Pusdiklat Teknis BPP Lampung, kemudahan penggunaan e-learning juga mempengaruhi kesediaan untuk menggunakan e-learning.

Kata Kunci : e-learning, Diklat Teknis, BPP Lampung, TAM 